\title{
The Rates of Synonymous and Nonsynonymous Substitutions in Sorbus aucuparia Using Nuclear and Chloroplast Genes
}

\author{
Man Kyu Huh* \\ Department of Molecular Biology, Dongeui University, 995 Eomgwangno, Busanjin-gu, Busan 614-714, Korea \\ Received January 12, 2010 / Accepted March 8, 2010
}

\begin{abstract}
The rates of synonymous and nonsynonymous nucleotide substitutions were studied for sequences of nuclear and chloroplast genes in Sorbus aucuparia. Results suggested that DNA evolution in this species had taken place, on average, at a slower rate in the chloroplast genes than in the nuclear genes: a rate variation pattern similar to those observed in eudicot plants. Within the nucleus, the synonymous substitution rates (Ks) (2.45-2.60) were two-fold higher than nonsynonymous substitution rates (Ka) (1.15-1.30). More notably, the values of Ks (1.20-1.26) were about six-fold higher than those of $\mathrm{Ka}(0.26-0.42)$ within the chloroplast genome. $\mathrm{Ka} / \mathrm{Ks}$ ratios for nuclear and chloroplast genes of $S$. aucuparia had mean values of 0.178 and 0.056 , respectively. A $\mathrm{Ka} / \mathrm{Ks}$ ratio $<1$ indicated negative (purifying) selection. The chloroplast genes had a lower effective number of codons (ENC) values (22.4-32.2) than those of nuclear genes (35.8-38.7). The analysis of the G+C content indicated that the chloroplast genes in this investigation had a higher preference for synonymous codons ending with $\mathrm{A}$ and $\mathrm{T}(\mathrm{G}+\mathrm{C}$ content range, 28.4-29.1\%) where there was a slight bias toward codons ending with $\mathrm{G}+\mathrm{C}(63.2-64.2 \%)$ in the nuclear genome.
\end{abstract}

Key words : Sorbus aucuparia, nuclear genes, chloroplast genes, synonymous, nonsynonymous

\section{Introduction}

The number of substitutions per site between nucleotides and sequences is one of the most fundamental quantity for molecular evolutionary studies. Particularly number estimation of synonymous nucleotide substitutions (Ks) and nonsynonymous nucleotide substitutions (Ka) per site separately has great importance due to their usage in reconstruction of molecular phylogenetic trees and statistical test for the neutral theory of molecular evolution [9].

Studies on DNA evolution have demonstrated that different taxa, genomes (nucleus, chloroplast, and mitochondrion), and genes within a genome have evolved at varying rates $[9,16,23]$.

To compensate for the limitations of chloroplast DNA (cpDNA), as well as to obtain additional and independent estimates of phylogeny and systematics, nuclear rDNA has been widely adopted as a tool in plant systematics, and is now as commonly used as cpDNA. At higher taxonomic levels the slowly evolving rRNA genes are used [13,21], while at lower taxonomic levels internal and external intergenic spacers are more commonly employed $[1,3,4]$.

\section{*Corresponding author}

Tel : +82-51-890-1529, Fax : +82-51-890-1521

E-mail : mkhuh@deu.ac.kr
Land plants RNA genes are organized into two distinct sets of tandem arrays [21]. The first set is composed $5 \mathrm{~S}$ rRNA genes and intergenic spacers in tandem arrays at one or more chromosomal loci. The second set includes the 18S-5.8S-26S rDNA cistron in tandem arrays at one or more chromosomal loci. Both sets of rDNA arrays have been used in systematic studies far more frequently than 5S [4]. As for cpDNA, the potential phylogenetic utility of rDNA is facilitied by its structure and molecular evolution. Ribosomal genes exist in tandem arrays of genes composed of hundreds to thousands of copies per array $[1,3]$. The higher copy number facilities evaluation of rDNA by both restriction site- and PCR-based strategies. In addition, the recreative structure of these arrays promotes a process of homogenization ('concerted evolution') that may result in a single predominant sequence across all copies and arrays [2,29]. This homogenization allows PCR products to be directly sequenced, generally yielding a single dominant sequence that is assumed to be representative of the underlying genomic sequences.

The genus Sorbus L. is small- to medium-sized trees of the North Temperate Zone [18]. They are members of the Maloideae subfamily of the family Rosaceae and are closely related to Malus and Pyrus [5]. Diploid species of the genus are insect pollinated and self incompatible [17]. The most 
widespread species in the genus is Sorbus aucuparia $\mathrm{L}$. (rowan, mountain ash), a pinnate-level species that can be found to Siberia and the far east of Russia [17].

This study had been conducted to obtain more clear view of the variability of synonymous and nonsynonymous substitution rates among $S$. aucuparia populations. Evaluation of several representative populations with nuclear ribosomal DNA internal transcribed spacer sequences (ITS) and chloroplast DNA sequences had been studied.

\section{Materials and Methods}

\section{Plant materials and DNA extraction}

Used protein-coding genes of this study were obtained from GenBank and recent studied by Huh et al. [8]. Table 1 lists the genes, taxa, and GenBank accession numbers. Data and alignments are available on request.

Among two populations all of the 15 plants were collected from Korea (Table 1). Seven and eight plants were randomly collected from the Mulhyanggi Arboretum in Osan-shi and the Gyeongnam Arboretum in Jinju-shi, respectively. Single young leaf per mature tree ( $\geq 5 \mathrm{yr}$ ) was sampled.

The genomic DNA of the samples were extracted from fresh leaves using the plant DNA Zol Kit (Life Technologies Inc., Grand Island, New York, USA) according to the manufacturer's protocol.

\section{ITS analysis}

Primer sets of about 20 bases in length were used for PCR analysis. These primers were based on well-characteristic DNA sequences and were designed making use of conserved regions of the $18 \mathrm{~S}$ and $28 \mathrm{~S}$ rRNA genes to amplify the noncoding regions between the ITS1, ITS2, and 5.8S rRNA genes [26].

PCR materials (50 ul) included $50 \mathrm{ng}$ of genomic DNA, $100 \mathrm{uM}$ of each dNTP, $0.2 \mathrm{uM}$ of each primer, $1 \mathrm{x}$ enzyme buffer, and 2 unit of Taq polymerase. The amplification profile was 28 cycles of $94^{\circ} \mathrm{C}$ for $30 \mathrm{sec}, 42^{\circ} \mathrm{C}$ for $60 \mathrm{sec}, 72^{\circ} \mathrm{C}$ for $60 \mathrm{sec}$, preceded by an initial denaturation at $94^{\circ} \mathrm{C}$ for $90 \mathrm{sec}$ and followed by a final extension at $72^{\circ} \mathrm{C}$ for $5 \mathrm{~min}$.

PCR products were separated on 1.5\% agarose gels and purified using the QIAquick Gel Extraction Kit (QIAGEN). The amplified fragments were cloned into a bluescript vector and sequenced using ABI Prism 377 Sequencer (Applied Biosystem, USA). At least seven individuals' clones of each population were analyzed.

The analysis of synonymous (Ks) and nonsynonymous (Ka) nucleotide substitutions

A pairwise alignment was calculated using the Clustal $X$ program. Phylogenetic relationships were estimated by MEGA4 version 4.0 treating all alignment gaps as missing [24].

The amino sequences of each gene were aligned in CLUSTALW [25] and the corresponding codons were matched between the taxa. A computer program written by Moriyama and Powell [15] based on the method described by Li [10] was used to estimate the Ks and Ka per site. This approach is likely to underestimate the $\mathrm{Ks}$ and Ka values for both the composition biases in both genomes [15]. Consequently, the rates of nucleotide substitutions per synonymous and nonsynonymous site per year, which were calculated by dividing Ks and Ka values by two times the estimated divergence time between the populations, are expected to be underestimated as well [27].

The expected numbers of Ks and Ka per site between two nucleotide sequences were computed [9]. That is,

$$
E(K s)=t \times E\left(S_{d}\right) / E(S)=t \times \frac{\sum_{\mathrm{i}=T T T}^{G G G} \sum_{j=T T T}^{G G G} S_{d i j} P_{i j} Q_{j}}{\sum_{i=T T T}^{G G G} S_{i} Q_{j}}
$$

Table 1. Accessions used in the molecular study of the Sorbus aucuparia, including population locations and GenBank accession numbers of this species

\begin{tabular}{lllc}
\hline \multicolumn{1}{c}{ Gene } & Code & \multicolumn{1}{c}{ Location } & Accession No. \\
\hline Nuclear & OSA & Osan-shi, Gyeonggi-do, Korea & This study \\
Nuclear & JIN & Jinju-shi, Gyeongsangnam-do, Korea & This study \\
Chloroplast & RUS & Apatity, Kola Peninsula, Russia & AJ430535 \\
Chloroplast & TUR & Kale, Bolu Provence, Turkey & AJ430536 \\
Chloroplast & GRE & Aristi, Pindus Mountains, Greece & AJ430537 \\
Chloroplast & FR-1 & Auvergne, France & AJ430538 \\
Chloroplast & FR-2 & Alsace, France & AJ430539 \\
\hline
\end{tabular}


$E(\mathrm{Ka})=t \times \mathrm{E}\left(\mathrm{A}_{\mathrm{d}}\right) / \mathrm{E}(\mathrm{A})=t \times \frac{\sum_{\mathrm{i}=\mathrm{TTT}}^{\mathrm{GGG}} \sum_{\mathrm{j}=\mathrm{TTT}}^{\mathrm{GGG}} \mathrm{N}_{\text {dij }} \mathrm{P}_{\mathrm{ij}} \mathrm{Q}_{\mathrm{j}}}{\sum_{\mathrm{i}=\mathrm{TTT}}^{\mathrm{GGG}} \mathrm{N}_{\mathrm{i}} \mathrm{Q}_{\mathrm{j}}}$

where $t$ is the total time that passed in the two lineages since the divergence of the two nucleotide sequences.

In the above formulation, transitional and transversional changes were not distinguish [9]. However, these changes can be calculated $\mathrm{E}(\mathrm{Ks}, \mathrm{Ts})$ and $\mathrm{E}\left(\mathrm{Ka}, \mathrm{Tv}_{\mathrm{v}}\right)$ separately, where $\mathrm{Ks}$,Tv are the numbers of synonymous transitional and transversional substitutions per site, respectively, between two nucleotide sequences of codons. The expected numbers of synonymous transitional and transversional substitutions per site between the two nucleotide sequences are given by

$$
\begin{aligned}
& \mathrm{E}\left(\mathrm{Ks}, \mathrm{Ts}_{\mathrm{s}}\right)=t \times \mathrm{E}\left(\mathrm{S}_{\mathrm{Ts}}\right) / \mathrm{E}(\mathrm{S}) \\
& \mathrm{E}\left(\mathrm{Ks}, \mathrm{Tv}_{\mathrm{v}}\right)=t \times \mathrm{E}\left(\mathrm{S}_{\mathrm{Tv}}\right) / \mathrm{E}(\mathrm{S})
\end{aligned}
$$

where $S_{\mathrm{Ts}}$ and $\mathrm{S}_{\mathrm{TV}}$ are the total numbers of synonymous transitional and transversional substitutions, respectively, during one evolutionary time unit between the two nucleotide sequences.

In pooling different genes to obtain the mean $\mathrm{K}$ for each genome, the $\mathrm{K}$ value for each gene was weighted by its number of sites (Ls or La). The standard error of the mean $\mathrm{K}$ was calculated as the square-root of the mean variance

$$
\mathrm{V}_{\mathrm{k}}=\left(\sum_{\mathrm{i}}\right)^{-2} \quad \sum_{\mathrm{j}} \mathrm{L}_{\mathrm{i}}^{2} \mathrm{~V}_{\mathrm{ki}}
$$

where $V_{k}$ and $L_{i}$ are the variance of $K$ and the $L s$ or $L a$ for the ith gene [27].

The program CODONS was used to calculate the degree of nonrandom usage of synonymous codons and the $\mathrm{G}+\mathrm{C}$ content in the third position [12]. The effective number of codons (ENC) is the measure that is employed to infer codon usage bias [28].

\section{Results}

Table 2 shows the synonymous and nonsynonymous nucleotide substitution rates in the nuclear and chloroplast genomes at the population levels. The absolute rate values derived from Ks distances for the chloroplast genes were lower than those for the nuclear genes. Comparative average numbers were similar between synonymous substitutions per site (Ks) in the nuclear (1.01) and chloroplast genomes (1.08). The exact magnitude of the average silent rate difference between the two genomes was difficult to access because the estimated numbers of synonymous substitution for the nuclear genes were most likely saturated. The average absolute nonsynonymous rates for the chloroplast genes were approximately three times slower than those calculated based on the nuclear Ka values (Table 2). The chloroplast genes were shown about a two and half fold differences between the slowest and the fastest silent rates. $\mathrm{Ka} / \mathrm{Ks}$ ratios for nuclear and chloroplast of $S$. aucuparia had the mean values of 0.178 and 0.056 , respectively. Ka/Ks ratio for nuclear was about six-fold higher than that of chloroplast.

Table 2. Estimated rates of synonymous (Ks) and nonsynonymous (Ka) substitution per synonymous and nonsynonymous site per year in nuclear and chloroplast genes

\begin{tabular}{lccccccccc}
\hline Gene & Code & Ls & La & Ks & Ka & Ka/Ks & Rate $(K s)$ & Rate $(K a)$ & ENC \\
\hline Nuclear & OSA & 3 & 14 & 0.99 & 0.17 & 0.172 & $2.4-2.6$ & $1.1-1.3$ & $38.7 / 45.4$ \\
Nuclear & JIN & 5 & 15 & 1.03 & 0.18 & 0.175 & $2.5-2.6$ & $1.2-1.3$ & $38.5 / 46.1$ \\
$\quad$ Mean & & 4.00 & 14.45 & 1.01 & 0.18 & 0.178 & $2.45-2.60$ & $1.15-1.30$ & $38.60 / 45.75$ \\
Chloroplast & RUS & 17 & 24 & 1.07 & 0.04 & 0.037 & $1.5-2.0$ & $0.2-0.5$ & $32.2 / 32.3$ \\
Chloroplast & TUR & 20 & 25 & 1.06 & 0.04 & 0.038 & $1.6-1.8$ & $0.3-0.4$ & $31.2 / 33.7$ \\
Chloroplast & GRE & 28 & 31 & 1.07 & 0.07 & 0.065 & $1.1-1.3$ & $0.3-0.4$ & $26.4 / 35.6$ \\
Chloroplast & FR-1 & 27 & 40 & 1.10 & 0.06 & 0.055 & $1.0-1.3$ & $0.2-0.3$ & $23.6 / 25.8$ \\
Chloroplast & FR-2 & 31 & 66 & 1.11 & 0.09 & 0.081 & $0.8-1.4$ & $0.3-0.5$ & $22.4 / 24.9$ \\
Mean & & 24.60 & 37.20 & 1.08 & 0.06 & 0.056 & $1.20-1.26$ & $0.26-0.42$ & $27.16 / 30.46$ \\
\hline
\end{tabular}

Ls and La are the number of synonymous and nonsynonymous sites, respectively.

$\mathrm{Ka}$ and $\mathrm{Ks}$ are the number of synonymous and nonsynonymous substitution per synonymous and nonsynonymous sites, respectively.

Rate (Ks) and rate (Ka) are substitutions per synonymous and nonsynonymous site per year, respectively.

ENC is codon usage bias. The number to the left of the line corresponds to the ENC value for the population to the left of the line under the population subheading. The number to the right of the line corresponds to the ENC value for the population to the right of the line under the population subheading. 
Within the nucleus, the mean rate (Ks) (2.45-2.60) was two-fold higher than mean rate (Ka) (1.15-1.30). The mean rate (Ks) (1.20-1.26) was about six-fold higher than mean rate (Ka) (0.26-0.42) within the chloroplast genomes. The chloroplast genes tended to have lower effective number of codons (ENC) values (22.4-32.2) than the nuclear ones (38.5-38.7).

The base furtherance showed the difference to the total taxon (Table 3). An averages $\mathrm{A}$ and $\mathrm{T}$ for chloroplast genomes were $31.7 \%$ and $39.5 \%$, respectively. $G$ and $C$ were $13.5 \%$ and $15.3 \%$ where in the nuclear genome there was a slight bias toward codons ending with $\mathrm{G}+\mathrm{C}(63.2-64.2 \%)$.

The distribution of rDNA variants within populations was not detected. Namely, Korean S. aucuparia populations were shown almost monomorphic and had 0.3-0.4\% within variation $(p>0.05)$. Whereas, the level of chloroplast DNA diversity was detected in $S$. aucuparia populations. All plants of $S$. aucuparia in Korea were introduced from Europe recently [8]. Although the two Korean populations of the $S$. aucuparia were isolated from each other, it is a possibility that they are introduced same population or region. Although alignments of the chloroplast sequences among populations were great similarity among the species' sequences, the unusual nucleotide inserts were shown in the Alsace population (Table 4). In addition, variations were observed in nucleotide substitutions and indels. The Auvergne

Table 3. Rates of A, C, G, and T in nuclear and chloroplast genes of $S$. aucuparia

\begin{tabular}{ccccc}
\hline Codes & A & C & G & T \\
\hline OSA & 18.0 & 36.3 & 27.9 & 17.8 \\
JIN & 18.8 & 35.7 & 27.5 & 18.0 \\
Mean & 18.4 & 36.0 & 27.7 & 17.9 \\
RUS & 30.0 & 16.0 & 12.9 & 41.4 \\
TUR & 29.8 & 14.9 & 13.7 & 41.6 \\
GRE & 31.0 & 15.5 & 12.9 & 40.6 \\
FR-1 & 33.0 & 15.1 & 13.7 & 38.1 \\
FR-2 & 34.9 & 14.9 & 14.2 & 36.0 \\
Mean & 31.7 & 15.3 & 13.5 & 39.5 \\
\hline
\end{tabular}

population (FR-1) in France had the repeated sequences of GCAAAATA. However it is unclear whether the sequences of GCAAAATA are inserted or lost of in some populations of S. aucuparia.

\section{Discussion}

The average absolute Ks for the chloroplast genes was lower than that for the nuclear genes. This is in accordance with the review by Raspe et al. [17] which reported the revel of differentiation among populations (Gst) of $S$. aucuparia was higher for chloroplast markers $(\mathrm{Gst}=0.286)$ than for nuclear (isozyme) markers (Gst=0.025).

Do many diversifications occur in a low taxon level such as population revel? The divergences of major clades of angiosperms occurred rapidly [22]. For example, molecular dating techniques provide a time frame for the likely rapid diversification of the five major lineages of Mesangiospermae (magnoliids, monocots, Chloranthaceae, eudicots, and Ceratophyllaceae). This diversification, ultimately yielding perhaps $97 \%$ of all angiosperm species, was rapid, occurring over a span of perhaps no more than 5 Myr [14,22].

One way to evaluate the selective pressures on protein evolution is to compare the rate of $\mathrm{Ks}$ and $\mathrm{Ka}$. Ks is the estimated number of synonymous changes per synonymous site and corresponds to the rate of amino acid- neutral evolution. Ka, on the other hand, is the number of nonsynonymous substitutions per nonsynonymous site. Under neutral protein- level evolution Ka should be equal to Ks and hence the ratio $\mathrm{Ka} / \mathrm{Ks}=1 . \mathrm{Ka} / \mathrm{Ks}>>1$ is candidate for functional adaptation. Deviations from this mark selective pressures at the protein level. It should be noted that Ks itself can be under selective pressures that do not act on $\mathrm{Ka}$, like selection for optimal expression level based upon codon use and tRNA concentration [6]. However, this effect is not expected to generate a large false positive rate in the use of $\mathrm{Ka} / \mathrm{Ks}$ to detect positive selection. $\mathrm{Ka} / \mathrm{Ks}$ ratios for nuclear and chloroplast of $S$. aucuparia had the mean values

Table 4. Comparison of populations of S. aucuparia on chloroplast DNA inserted sequences

\begin{tabular}{|c|c|c|c|c|c|}
\hline \multirow[t]{2}{*}{ Code } & \multicolumn{5}{|c|}{ Sequences } \\
\hline & 160 & & 170 & & 180 \\
\hline RUS & AAGCAAAATA & & AGGTGTATAA & & ACAGAACTTC \\
\hline TUR & AAGGAAAATA & & AGCAAA-TAA & & GGTGTATAAA \\
\hline GRE & AAGGAAAATA & GCAAAATA & AGGAAAATAA & & ACAGAACTTC \\
\hline FR-1 & AAGGAAAATA & GCAAAATAAGCAAAATA & AGGTGTATAA & & ACAGAACTTC \\
\hline Fr-2 & AAGGAAAATA & & AGGAAAATAA & GGAAAATAAGCAAAATAAGCAAAATAAGGTGTATAA & ACAGAACTTC \\
\hline
\end{tabular}


of 0.178 and 0.056 , respectively. A Ka/Ks ratio $<1$ indicates negative (purifying) selection [6]. The ENC ranges from 20 to 61 , the former indicating extreme bias and the latter equal usage of synonymous codons [28].

Studying the evolution of protein-coding genes, it is useful to distinguish between synonymous and nonsynonymous substitutions, and many methods have been proposed for estimating the numbers of the two types of substitution between two sequences [10]. The counting rule can considerably over estimate the Ks value because transitional mutations tend to occur more often than transversional mutations and because most transitional mutations at two fold degenerate sites are synonymous [10]. Proposed methods of this study are modification of Li et al's methods [11]. For example, the nucleotide sites in a sequence are classified into nondegenerate, twofold degenerate, and fourfold degenerate sites. A site is nondegenerate of all possible changes at that site are nonsynonymous, twofold degenerate if one of the three possible changes is synonymous, and fourfold degenerate of all possible changes at the site are synonymous.

The analysis of the G+C content indicated that the chloroplast genes included in this investigation had a higher "preference" for synonymous codons ending with $\mathrm{A}$ and $\mathrm{T}$ $(\mathrm{G}+\mathrm{C}$ content range, 28.4-29.1\%), where the nuclear genome had a slight bias toward codons ending with $\mathrm{G}+\mathrm{C}$ $(63.2-64.2 \%)$. The base furtherance of $\mathrm{G}+\mathrm{C}$ was showed about $64.6 \%$ for four Sorbus taxa [8]. The values are similar to them of S. amurensis (63.8\%), S. sambucifolia var. pseudogracilis $(64.9 \%)$, and S. commixta (65.5\%).

Despite the limited sample of genes, the results suggested that the chloroplast DNA in S. aucuparia has evolved at a slower average rate than observed in the nuclear DNA. This result is consistent with the findings from a much larger sample of land plant genes, obtained initially from eudicots, which showed the average synonymous and nonsynonymous substitution rates in the nuclear genes are about three to six times faster than those of chloroplast genes $[7,27]$.

The observed variation in the Ka-derived absolute rates among genes within each genome and between the chloroplast and the nuclear genomes can be attributed to differences in functional constraints on protein sequences. Several studies showed that differences in synonymous substitution rates among genes are negatively correlated with codon usage bias $[19,20]$. Biases in codon usage can arise if point mu- tations are not random and/or as a result of natural selection $[9,22]$. Further investigations are required to confirm synonymous substitution rate differences between nuclear and chloroplast genes.

\section{References}

1. Alvarez, I. and J. F. Wendel. 2003. Ribosomal ITS sequences and plant phylogenetic inference. Mol. Phylogen. Evol. 29, 417-434.

2. Arnheim, N. 1983. Concerted evolution of multigene families, pp. 38-61, In Nei, M. and P. K. Koehn (eds.), Evolution and Proteins, Sinauer, Sunderland, MA.

3. Bailey, C. D., T. G. Carr, S. A. Harris, and C. E. Hughes. 2003. Characterization of angiosperm nrDNA polymorphism, paralogy, and psudogenes. Mol. Phylogen. Evol. 29, 435-455.

4. Baldwin, B. G., M.J. Sanderson, J. M. Porter, M. F. Wojciechowski, C. S. Campbell, and M. G. Donoghue. 1995. The ITS region of nuclear ribosomal DNA: a valuable source of evidence on angiosperm phylogeny. Ann. Missouri Bot. Gard. 82, 247-277.

5. Campbell, C. S., M. J. Donoghue, B. G. Baldwin, and M. F. Wojciechowski. 1995. Phylogenetic relationships in Maloideae (Rosaceae): evidence from sequences of the internal transcribed spacers of nuclear ribosomal DNA and its congruence with morphology. Am. J. Bot. 82, 903-918.

6. Duret, L. 2000. tRNA gene number and codon usage in the C. elegans genome are co-adapted for optimal translation of highly expressed genes. Trends in Genetics 16, 287-289.

7. Gaut, B. S. 1997. Molecular clocks and nucleotide substitution rates in higher plants, pp. 93-116, In Hecht, M. K., R. J. MacIntyre, and M. T. Clegg (eds.), Evolutionary Biology, Vol 30, Plenum Press, New York.

8. Huh, M. K., S. H. Kim, and S. H. Park. 2007. Phylogenetic study of genus Sorbus in Korea by internal transcribed spacer sequence (ITS). J. Life Sci. 17, 1610-1615.

9. Ino, Y. 1995. New methods for estimating the numbers of synonymous and nonsynonymous substitutions. J. Mol. Evol. 40, 190-226.

10. Li, W. H. 1993. Unbiased estimation of the rates of synonymous and nonsynonymous substitution. J. Mol. Evol. 36, 96-99.

11. Li, W. H., C. I. Wu, and C. C. Luo. 1985. A new method for estimating synonymous and nonsynonymous rates of nucleotide substitution considering the relative likelihood of nucleotide and codon changes. Mol. Biol. Evol. 2, 150-174.

12. Lloyd, A. T. and P. M. Sharp. 1992. CODONS: a microcomputer program for codon usage analysis. J. Hered. 83, 239-240.

13. Kuzoff, R. K., J. A. Sweere, D. E. Soltis, and E. A. Zimmer. 1998. The phylogenetic potential of entire $26 \mathrm{~S}$ rDNA sequences in plants. Mol. Biol. Evol. 15, 251-263.

14. Moore, M. J., A. Dhingra, P. S. Soltis, R. Shaw, W. G. 
Farmerie, K. M. Folta, and D. E. Soltis. 2006. Rapid and accurate pyrosequencing of angiosperm plastid genomes. BMC Plant Biol. 6, 17-30.

15. Moriyama, E. N. and J. R. Powell. 1997. Synonymous substitution rates in Drosophila: mitochondrial versus nuclear genes. J. Mol. Evol. 45, 378-391.

16. Palmer, J. D., K. L. Adams, Y. Cho, C. L. Parkinsonv, Y. L. Qiu, and K. Song. 2000. Dynamic evolution of plant mitochondrial genomes: mobile genes and introns and highly variable mutation rates. Proc. Natl. Acad. Sci. USA. 97, 6960-6966.

17. Raspe, O., P. Saumitou-Laprade, J. Cuguen, and A. L. Jacquemart. 2000. Chloroplast DNA haplotype variation and population differentiation in Sorbus aucuparia $\mathrm{L}$. (Rosaceae: Maloideae). Mol. Ecol. 9, 1113-1122.

18. Robertson, K. R., J. B. Phipps, J. R. Rohrer, and P. G. Smith. 1991. A synopsis of genera in Maloideae (Rosaceae). Syst. Bot. 16, 376-394.

19. Sharp, P. M., D. C. Sields, K. H. Wolfe, and W. H. Li. 1989. Chromosomal location and evolutionary rate variation in enterobacterial genes. Science 246, 808-810.

20. Shields, D. C., P. M. Sharp, D. G. Higgins, and F. Wright. 1988. "Silent" sites in Drosophila genes are not neutral: evidence of selection among synonymous codons. Mol. Biol. Evol. 5, 704-716.

21. Small, R. L., R. C. Cronn, and J. F. Wendel. 2004. Use of nuclear genes for phylogeny reconstruction in plants. Aust. J. Bot. 17, 145-170.

22. Soltis, D. E., C. D. Bell, S. Kim, and P. S. Soltis. 2008. Origin and early evolution of angiosperms. Ann. N.Y. Acad. Sci.
1133, 3-25.

23. Sorhannus, U. and M. Fox. 1999. Synonymous and nonsynonymous substitution rates in diatons: a comparison between chloroplast and nuclear genes. J. Mol. Evol. 48, 209-212.

24. Tamura, K., J. Dudley, M. Nei, and S. Kumar. 2007. MEGA4: Molecular evolutionary genetics analysis (MEGA) software version 4.0. Mol. Biol. Evol. 24, 1596-1599.

25. Thompson, J. D., D. G. Higgins, and T. J. Gibson. 1994. CLUSTAL W: improving the sensitivity of procreative multiple sequence alignment through sequence weighting, position-specific gap penalties and weight matrix choice. Nucleic Acids Res. 22, 4673-4680.

26. White, T. J., T. Bruns, S. Lee, and J. Taylor. 1999. Amplification and direct sequencing of fungal ribosomal genes for phylogenetics, pp. 315-322, In Innis, M. A., D. H. Gelfand, J. J. Sninsky, and T. J. White (eds.), PCR Protocols: A Guide to Methods and Applications, New York Academic Press.

27. Wolfe, K. H., W. H. Li, and P. M. Sharp. 1987. Rates of nucleotide substitution vary greatly among plant mitochondrial, chloroplast, and nuclear DNAs. Proc. Natl. Acad. Sci. USA. 84, 9054-9058.

28. Wright, F. 1990. The "effective number of codons" used in a gene. Gene 87, 23-29.

29. Zimmer, E. A., S. L. Martin, S. M. Beverly, W. Kan, and A. C. Wilson. 1980. Rapid duplication and loss of genes coding for the a chains of hemoglobin. Proc. Natl. Acad. Sci. USA. 77, 2158-2162.

\section{초록 : 핵 및 엽록체 유전자를 이용한 유럽마가목에서 동의 및 비동의치환율}

허 만 귳

(동의대학교 분자생물학과)

유럽마가목에서 핵 및 엽록체 유전자의 서열을 이용하여 동의 및 비동의치환율을 산출하였다. 유럽마가목 엽 록체 유전자의 서열은 핵 유전자에 비해 평균적으로 움진화가 느리게 일어나고 있음을 나타내었으며 다른 쌍자 엽식물과 유사하였다. 핵에서 동의치환율(Ks)은 2.45-2.60이었으며 비동의치환율(Ka=1.15-1.30)보다 약 2배 정도 높았다. 엽록체에서 Ks는 1.20-1.26이었으며 엽록체에서 Ka (0.26-0.42) 보다 약 6배 높았다. 유럽마가목에서 핵 및 엽록체 $\mathrm{Ka} / \mathrm{Ks}$ 은 각각 0.178 과 0.056 이었다. 이 $\mathrm{Ka} / \mathrm{Ks}$ 의 비율이 1 보다 작다는 것은 음의 도태에 있다는 것을 나타낸다. 엽록체 유전자는 유효유전자코돈(ENC)이 22.4-32.2로 핵의 값(35.8-38.7)에 비해 낮았다. G+C 함량 분 석에서 엽록체 유전자는 동의코돈 $\mathrm{A}$ 와 T에 대해 높은 선호성 $(\mathrm{G}+\mathrm{C}$ 함량은 28.4-29.1\%에 불과)을 나타낸 반면 핵 에서는 $\mathrm{G}$ 와 $\mathrm{C}$ 가 더 선호성을 나타내었다 $(\mathrm{G}+\mathrm{C}$ 함량은 63.2-64.2\%). 